\title{
Menghitung Distribusi Tekanan Udara dan Gaya Hambat Kepala Pesawat BOEING 777-200
}

\author{
Djoko Poernomo dan Satwiko Sidopekso* \\ Jurusan Fisika Universitas Negeri Jakarta \\ Jl. Rawamangun Muka, Jakarta 13220 \\ Tri Susilo \\ Jurusan Teknik Kedirgantaraan Universitas Suryadarma \\ Jl. Dirgantara, Halim Perdanakusuma, Jakarta
}

\begin{abstract}
Intisari
Pesawat terbang akan mengalami beberapa gaya akibat adanya distribusi tekanan udara yang terjadi disekitar pesawat. Salah satu gaya yang bekerja adalah gaya hambat (drag). Distribusi tekanan udara tidak hanya dipengaruhi oleh bentuk dari benda tetapi dipengaruhi sudut serang yang terbentuk antara aliran udara dengan benda dan juga kecepatan aliran udara. Dengan menggunakan terowongan angin Suryadarma Low Speed Tunnel WT-400, dilakukan pengujian terhadap kepala pesawat Boeing 777-200 terhadap perubahan sudut serang dan kecepatan aliran. Sebagai perbandingan dilakukan pula pengujian terhadap dua benda yang berbeda.
\end{abstract}

KATA KUNCI: distribusi tekanan udara, gaya hambat

\section{PENDAHULUAN}

Sistem aerodinamik pada pesawat terbang dapat diamati apabila ada aliran udara yang bergerak melalui permukaan pesawat terbang. Bila suatu benda berada pada suatu aliran udara, maka akan terjadi gesekan atau gaya geser. Gesekan yang terjadi adalah gesekan antara partikel-partikel udara dengan permukaan benda yang dilaluinya. Karena adanya gesekan tersebut, maka kecepatan tiap-tiap lapisan menjadi berkurang yang diakibatkan oleh gaya hambat sehingga akan berpengaruh terhadap distribusi tekanan yang terjadi di sepanjang permukaan benda.

Akibat adanya distribusi tekanan dan gaya gesek yang terjadi di sepanjang permukaan pesawat, maka akan ada gayagaya yang bekerja pada pesawat yaitu resultan gaya aerodinamik $(\mathrm{R})$ dan gaya momen $(\mathrm{M})$. Resultan gaya dapat dibagi menjadi beberapa komponen yaitu komponen yang tegak lurus dan komponen yang sejajar sumbu koordinat. Komponenkomponen gaya yang sejajar dengan sumbu koordinat dan arahnya berlawanan dengan arah laju pesawat disebut dengan gaya hambat (D). Untuk mengetahui distribusi tekanan yang terjadi dapat dilakukan eksperimen dengan menggunakan beberapa metode. Metode pertama yaitu dimana objek bergerak dan fluida diam (bergerak relatif terhadap benda), salah satunya dengan uji terbang. Metode kedua yaitu benda diam dan fluidanya bergerak.

Penelitian ini bertujuan untuk mengetahui distribusi tekanan udara dan besarnya gaya hambat pada kepala pesawat Boeing 777-200 serta mengetahui perubahan yang terjadi terhadap perubahan sudut serang dan kecepatan aliran udara.

*E-MAIL: sidopekso61@yahoo.com.au

\section{LANDASAN TEORI}

\section{A. Aerodinamika}

Aliran udara bila dikaitkan dengan kekentalannya (viskositas), maka aliran udara tersebut dapat dibedakan atas dua jenis aliran, yaitu aliran viskos (viscid flow) dan aliran tak-viskos (inviscid flow), sedangkan jika sifat aliran udara dikaitkan dengan kerapatannya (densitas), maka aliran udara tersebut dapat dibedakan juga atas dua jenis aliran, yaitu aliran termampatkan (compressible flow) dan aliran tak-termampatkan (incompressible flow).

Berdasarkan persamaan kontinuitas dengan menggunakan prinsip konservasi massa suatu aliran yang melalui suatu ruang:

$$
\frac{\partial \rho}{\partial t}+\frac{\partial}{\partial x}(\rho . u)+\frac{\partial}{\partial y}(\rho . u)=0
$$

Untuk penyederhanaan, aliran yang terjadi dianggap invicid dan incompresible, maka aliran dapat didefinisikan:

$$
\nabla \bullet \vec{V}=0
$$

Untuk mencari besar koefisien tekanan $\left(\mathrm{C}_{P}\right)$ dapat digunakan persamaan Bernoulli, bahwa jumlah energi potensial, energi kinetik dan tekanan adalah konstan

$$
p+\frac{1}{2} \rho v^{2}=\text { konstan }
$$

dengan membandingkan perubahan tekanan sebelum dan sesudah melewati benda, besarnya koefesien tekanan adalah:

$$
C_{p}=\frac{p-p_{\circ}}{\frac{1}{2} \rho_{\circ} v_{\circ}^{2}}
$$


Sedangkan besarnya gaya hambat:

$$
\begin{array}{r}
C_{D}=\frac{D}{q_{\propto} S} \\
D=-\int\left(p-p_{\propto}\right) \cos \theta d S
\end{array}
$$

\section{METODOLOGI}

Eksperimen dilakukan dengan menggunalan terowongan angin (wind tunnel) Suryadarma Low Speed Tunnel (SLST $W T-400)$ dengan tiga macam benda uji yaitu berbentuk silinder, berbentuk nose dan berbentuk kepala pesawat jenis Boeing 777-200. Data yang diperoleh dari hasil eksperimen adalah data ketinggian permukaan air pada tabung manometer untuk masing-masing titik uji, kecepatan dan sudut serang. Dari hasil ini kemudian akan diolah menjadi koefisien tekanan $\left(\mathrm{C}_{P}\right)$ yang merupakan perbandingan antara tekanan yang terjadi di titik uji permukaan benda uji terhadap tekanan pada udara bebas dengan rumus:

$$
C_{p}=\frac{h_{1}-h}{h_{1}-h_{2}}
$$

Akan diperoleh koefisien tekanan $\left(\mathrm{C}_{p}\right)$ pada tiap-tiap titik uji. Dengan merubah sudut serang dan kecepatan aliran udara, maka akan diperoleh variasi data untuk masing masing kondisi.

Data untuk tiap-tiap kondisi kemudian akan diolah menjadi distribusi tekanan udara disekitar benda uji. Untuk memperoleh distribusi tekanan udara yang didefinisikan sebagai persamaan differensial parsial dapat menggunakan program komputer SciLab dengan solusi numerik menggunakan metode beda hingga (finite difference method).

Metode beda hingga menggunakan turunan kedua untuk menyelesaikan persamaan, yang dapat ditulis sebagai:

$$
\frac{d^{2} f}{d x^{2}} \approx \frac{1}{h^{2}}\{f(x+h)+f(x-h)-2 f(x)\}
$$

dengan $\mathrm{h}$ adalah interval antara koordinat titik. Untuk persamaan dengan dua variabel $\mathrm{f}(\mathrm{x}, \mathrm{y})$ dapat kita nyatakan dalam bentuk grid berupa koordinat-koordinat titik pada bidang dengan $\mathrm{x}=\mathrm{ih}$ dan $\mathrm{y}=\mathrm{jh}(\mathrm{i}, \mathrm{j}=1,2,3, \ldots)$ maka persamaan di atas dapat tuliskan menjadi

$$
\frac{1}{h^{2}}\left\{\phi_{i+1, j}+\phi_{i-1, j}+\phi_{i, j+1}+\phi_{i, j-1}-4 \phi_{i, j}\right\}
$$

dengan $\phi_{i, j}$ adalah titik pada koordinat $(i, j)$.

Nilai suatu titik pada suatu koordinat dipengaruhi oleh nilai pada titik di sekitar titik tersebut (lihat Gambar ??), maka Pers. 8 dapat disederhanakan menjadi

$$
\phi_{i, j}=\frac{\phi_{i+1, j}+\phi_{i-1, j}+\phi_{i, j+1}+\phi_{i, j-1}}{4}
$$

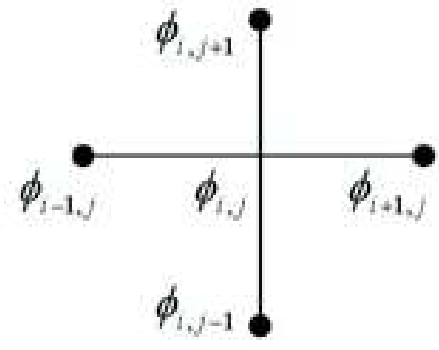

Gambar 1:

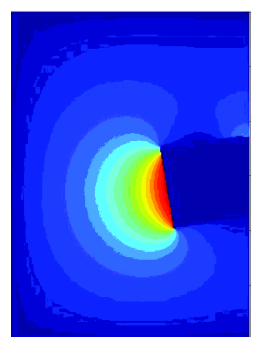

(a)

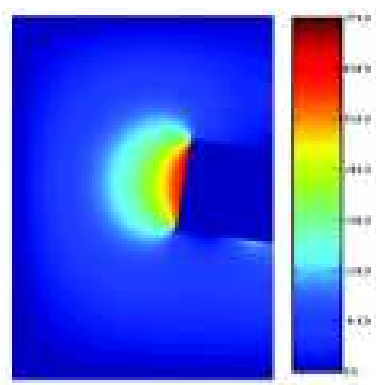

(c)

Gambar 2: Distribusi tekanan udara di sekitar benda uji silinder untuk sudut (a). $-9^{\circ}$, (b). $0^{\circ}$ dan (c). $9^{\circ}$

\section{HASIL PENELITIAN}

\section{A. Distribusi Tekanan Udara}

Distribusi tekanan udara yang diperoleh untuk kecepatan putaran 2016 rpm pada benda uji pertama ditunjukkan Gambar 2 . Pada sudut serang $0^{\circ}$, di sisi depan benda uji mengalami tekanan yang terbesar sedangkan pada sisi bagian atas dan bawah benda uji besarnya tekanan hampir sama. Pada sudut serang $-9^{\circ}$ dan $9^{\circ}$, di sisi depan benda uji masih mengalami tekanan yang terbesar namun pada sisi atas dan bawah benda uji terjadi perbedaan tekanan. Pada sudut serang $-9^{\circ}$ tekanan pada bagian belakang sisi atas lebih besar dibandingkan dengan tekanan pada bagian belakang sisi bawah. Dan sebaliknya pada sudut serang $9^{\circ}$, tekanan pada bagian belakang sisi atas lebih kecil dibandingkan dengan tekanan pada bagian belakang sisi bawah. 


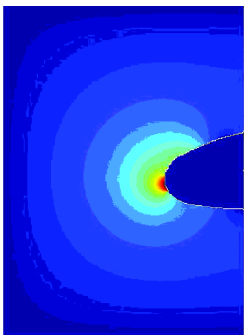

(a)

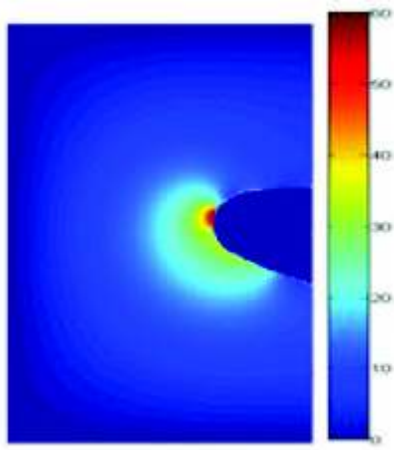

(c)

Gambar 3: Distribusi tekanan udara di sekitar benda uji Nose untuk sudut (a). $-9^{\circ},\left(\right.$ b) $.0^{\circ}$ dan (c). $9^{\circ}$

Untuk benda uji kedua yaitu berbentuk nose diperoleh hasil seperti ditunjukkan Gambar 3. Pada sudut serang $0^{\circ}$ terlihat bahwa tekanan terbesar terjadi di bagian depan benda uji sedangkan distribusi tekanan pada bagian atas dan bawah benda uji hampir sama. Pada sudut serang $-9^{\circ}$, tekanan terbesar terjadi di bagian depan benda uji namun dibagian depan sisi atas terjadi tekanan yang lebih besar bila dibandingkan bagian depan sisi bawah. Hal ini terjadi akibat permukaan benda uji bagian atas langsung menghadap arah aliran udara. Dan sebaliknya terjadi pada sudut $9^{\circ}$ yaitu bagian depan sisi atas mengalami tekanan yang lebih kecil dibandingkan bagian depan sisi bawahnya.

Hasil untuk benda uji ketiga yaitu berbentuk kepala pesawat Boeing 777-200, ditunjukkan Gambar 4. Untuk sudut serang $0^{\circ}$ terjadi peningkatan tekanan pada bagian depan dan bagian atas dari hidung pesawat. Hal ini disebabkan karena aliran udara yang mengalir di bagian atas hidung pesawat, terhambat oleh bagian kaca depan kokpit sehingga terjadi penumpukan partikel-partikel udara yang mengakibatkan meningkatnya densitas sehingga tekanan udara meningkat. Sedangkan pada bagian atas belakang dan bawah belakang distribusi tekanannya hampir sama. Pada sudut serang $-9^{\circ}$, tekanan terbesar terjadi pada bagian atas dari hidung pesawat hingga bagian jendela kaca sedangkan pada bagian atas lebih besar di bandingkan dengan bagian bawah. Pada sudut serang $9^{\circ}$ masih terdapat tekanan yang besar di sekitar hidung pesawat bagian atas sedangkan pada bagian bawah tekanan terbesar terjadi di sekitar hidung bagian bawah hingga kokpit bagian bawah.

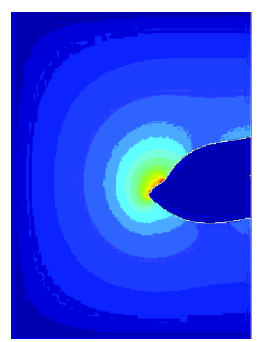

(a)

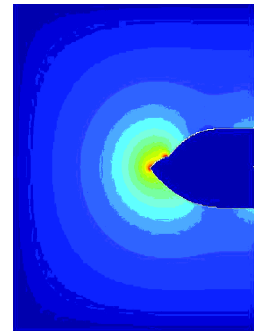

(b)

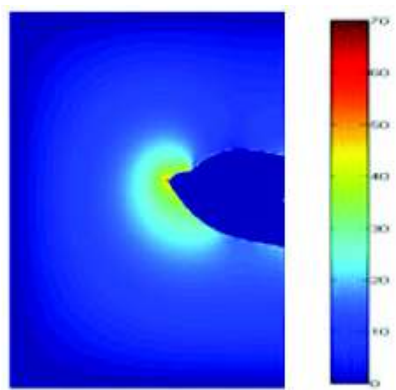

(c)

Gambar 4: Distribusi tekanan udara di sekitar benda uji Boeing 777200 untuk sudut (a). $-9^{\circ}$, (b). $0^{\circ}$ dan (c). $9^{\circ}$.

TABEL I: Gaya hambat pada benda uji silinder dengan perubahan kecepatan dan sudut serang.

\begin{tabular}{llll}
\hline \hline $\begin{array}{l}\text { Sudut } \\
\text { serang }\end{array}$ & RPM1663 & Gaya Hambat Silinder $(\mathrm{N})$ & \\
\hline-9 & 0.003307 & 0.003714 & 0.004454 \\
-7 & 0.003251 & 0.003775 & 0.004577 \\
-5 & 0.003227 & 0.003824 & 0.004563 \\
-3 & 0.003215 & 0.003868 & 0.004572 \\
0 & 0.00324 & 0.003894 & 0.004547 \\
3 & 0.003229 & 0.003882 & 0.004503 \\
5 & 0.003241 & 0.003865 & 0.004473 \\
7 & 0.003243 & 0.003867 & 0.004478 \\
9 & 0.003214 & 0.00386 & 0.00448 \\
11 & 0.003235 & 0.003837 & 0.004478 \\
13 & 0.00322 & 0.003817 & 0.004485 \\
15 & 0.003227 & 0.003775 & 0.004468 \\
17 & 0.003231 & 0.003702 & 0.004385 \\
19 & 0.003201 & 0.003618 & 0.004317 \\
21 & 0.003261 & 0.003531 & 0.00416 \\
\hline \hline
\end{tabular}

\section{B. Gaya Hambat}

Gaya hambat yang terjadi pada masing-masing benda uji dapat dilihat pada Tabel I. Pada Gambar 5 berdasarkan grafik tersebut terlihat bahwa terjadi perubahan gaya hambat terhadap perubahan sudut serang. Gaya hambat yang terbesar terjadi pada saat kecepatan yang terbesar. Sedangkan pada sudut serang $17^{\circ}$ hingga $21^{\circ}$ terjadi penurunan gaya hambat, hal ini disebabkan karena terjadinya perubahan posisi permukaan pada bagian depan terhadap arah aliran udara.

Pada kecepatan $1865 \mathrm{rpm}$, gaya hambat terbesar terjadi 


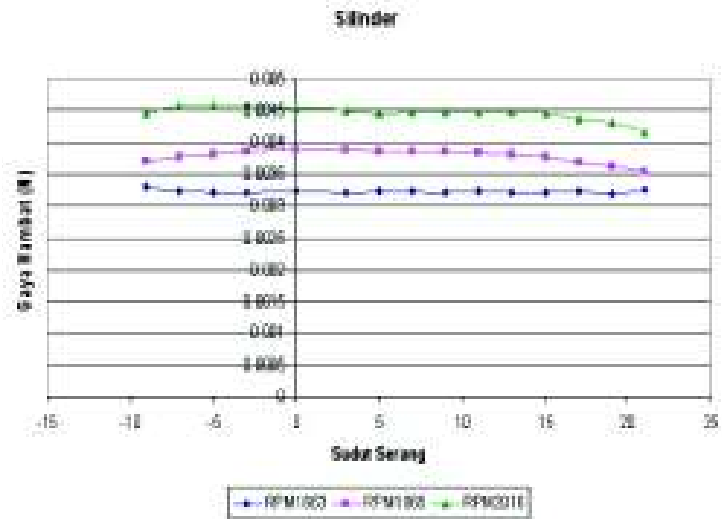

Gambar 5: Grafik gaya hambat terhadap perubahan sudut serang dan perubahan kecepatan pada benda uji silinder.

TABEL II: Gaya hambat pada benda uji Nose dengan perubahan kecepatan dan sudut serang.

\begin{tabular}{|c|c|c|c|}
\hline \multirow{2}{*}{$\begin{array}{l}\text { Sudut } \\
\text { serang }\end{array}$} & \multicolumn{3}{|c|}{ Gaya Hambat Nose (N) } \\
\hline & RPM1663 & RPM1865 & RPM2016 \\
\hline-9 & 0.001136 & 0.00145 & 0.001799 \\
\hline-7 & 0.001174 & 0.001531 & 0.001856 \\
\hline-5 & 0.001198 & 0.001602 & 0.001845 \\
\hline-3 & 0.001222 & 0.001667 & 0.001855 \\
\hline 0 & 0.001244 & 0.001682 & 0.0019 \\
\hline 3 & 0.001249 & 0.001657 & 0.001888 \\
\hline 5 & 0.001264 & 0.001603 & 0.001904 \\
\hline 7 & 0.001262 & 0.001528 & 0.001906 \\
\hline 9 & 0.001264 & 0.001451 & 0.001914 \\
\hline 11 & 0.001266 & 0.001412 & 0.001897 \\
\hline 13 & 0.001271 & 0.0014 & 0.001884 \\
\hline 15 & 0.001293 & 0.001403 & 0.001898 \\
\hline
\end{tabular}

pada sudut serang $0^{\circ}$ sedangkan pada sudut besar terjadi penurunan gaya hambat.

Gaya hambat terkecil terjadi pada saat sudut serang yang kecil, pada saat udara mengalir dan terhambat pada bagian depan, aliran udara akan terpecah mengalir melalui bagian atas dan melalui bagian bawah. Namun pada sudut serang yang besar gaya hambat meningkat.

Untuk membandingkan gaya hambat ketiga macam benda uji dapat dilihat melalui grafik seperti ditunjukkan Gambar 8 .

Berdasarkan grafik tersebut terlihat bahwa silinder memiliki gaya hambat yang paling besar bila dibandingkan dengan benda uji lainnya. Hal ini disebabkan karena adanya perbedaan luas permukaan benda uji. Bentuk silinder memiliki luas permukaan yang lebih besar bila dibandingkan dengan bentuk nose ataupun bentuk kepala pesawat sehingga tekanan pada permukaan menjadi semakin besar yang mengakibatkan gaya hambat menjadi semakin besar.

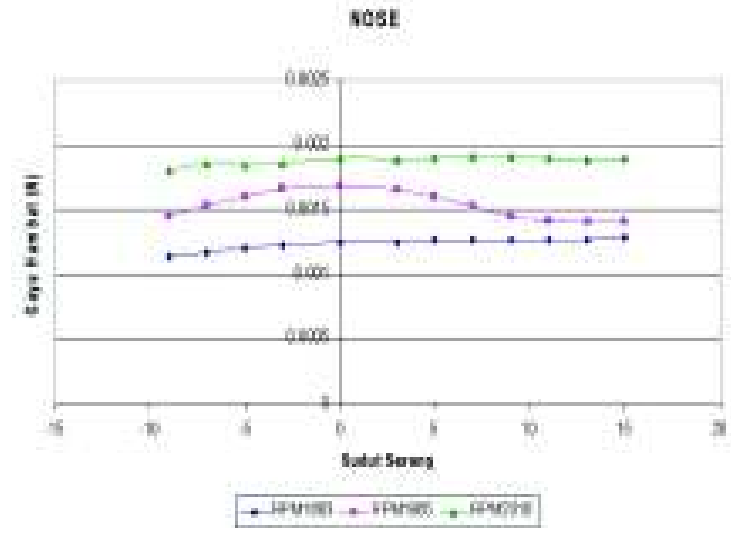

Gambar 6: Grafik gaya hambat terhadap perubahan sudut serang dan perubahan kecepatan pada benda uji Nose.

TABEL III: Gaya hambat pada benda uji Kepala Pesawat Boeing 777-200 dengan perubahan kecepatan dan sudut serang.

\begin{tabular}{llll}
\hline \hline Sudut & \multicolumn{3}{c}{ Gaya Hambat Kepala Pesawat (N) } \\
serang & RPM1663 & RPM1865 & RPM2016 \\
\hline-9 & 0.001311 & 0.001719 & 0.001976 \\
-7 & 0.001269 & 0.00175 & 0.002025 \\
-5 & 0.001256 & 0.001693 & 0.001997 \\
-3 & 0.001265 & 0.00168 & 0.001988 \\
0 & 0.001257 & 0.001637 & 0.001973 \\
3 & 0.001234 & 0.001616 & 0.001919 \\
5 & 0.001241 & 0.001629 & 0.001907 \\
7 & 0.001254 & 0.001652 & 0.001906 \\
9 & 0.001251 & 0.001654 & 0.001904 \\
11 & 0.001281 & 0.001747 & 0.00195 \\
13 & 0.00138 & 0.001746 & 0.002016 \\
15 & 0.00149 & 0.001791 & 0.002143 \\
17 & 0.001601 & 0.001928 & 0.002309 \\
19 & 0.001763 & 0.001992 & 0.002491 \\
21 & 0.001838 & 0.002339 & 0.002766 \\
\hline \hline
\end{tabular}

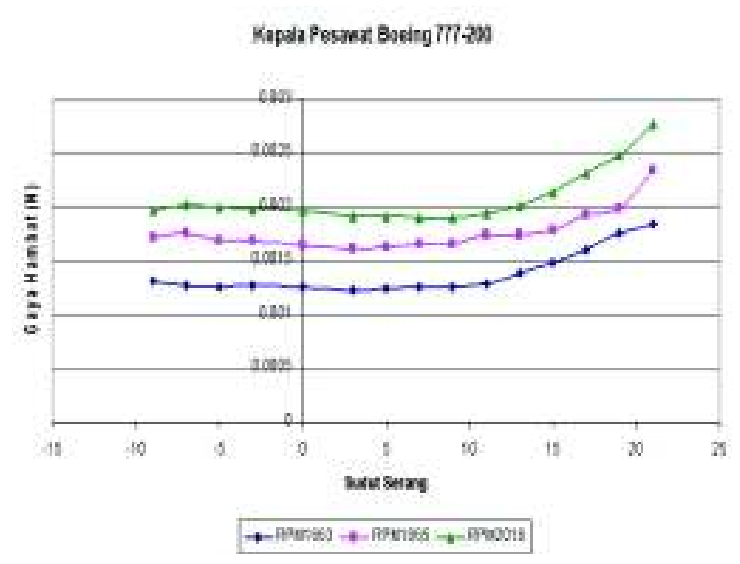

Gambar 7: Grafik gaya hambat terhadap perubahan sudut serang dan perubahan kecepatan pada benda uji Kepala Pesawat 
RPM1663

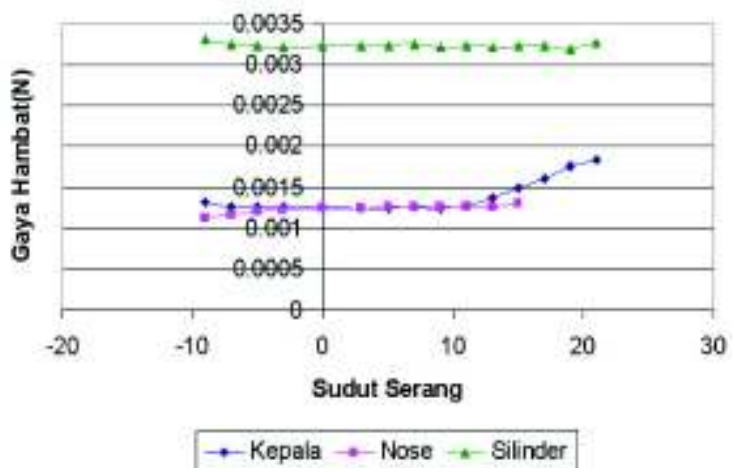

(a)
RPM 1865

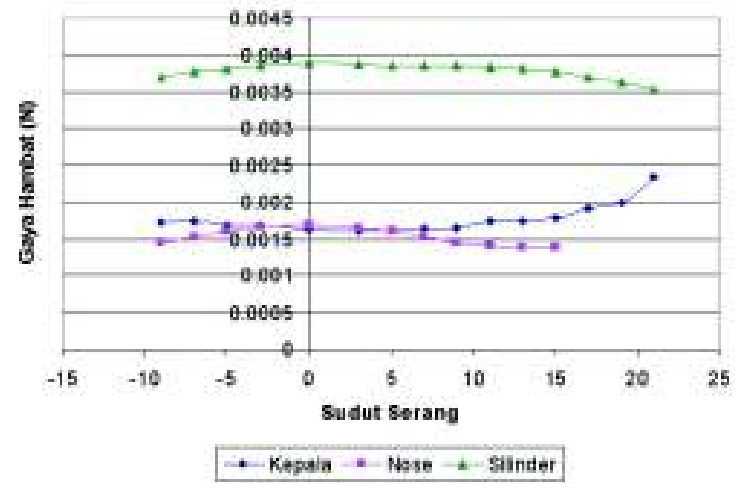

(b)

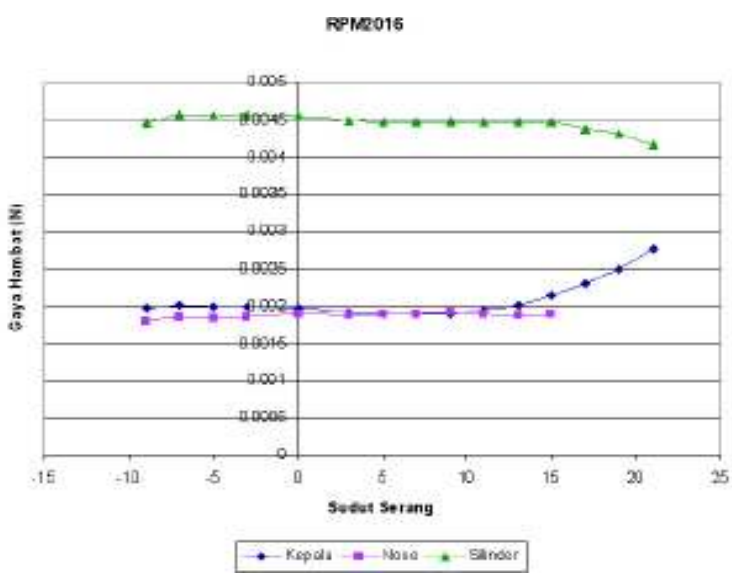

(c)

Gambar 8: Grafik gaya hambat pada masing-masing benda uji dengan kecepatan: (a) $1663 \mathrm{rpm}$, (b)1865 rpm dan (c) $2016 \mathrm{rpm}$.

\section{SIMPULAN}

Berdasarkan hasil penelitian dan analisa data yang telah di uraikan pada bab sebelumnya, besarnya gaya hambat yang terjadi bergantung dari kecepatan aliran dan perubahan sudut serang, maka dapat dibuat beberapa kesimpulan sebagai berikut:

1. Gaya hambat dipengaruhi oleh bentuk benda uji. Untuk kecepatan dan sudut serang yang sama, masing-masing benda uji memiliki nilai gaya hambat yang berbeda. Pada benda uji silinder diperoleh hasil berkisar antara $0.0033-0.0041 \mathrm{~N}$, pada benda uji nose diperoleh hasil berkisar antara $0.0011-0.0018 \mathrm{~N}$, sedangkan pada benda uji kepala Boeing 777-200 diperoleh hasil berkisar antara $0.0013-0.0027 \mathrm{~N}$.

2. Peningkatan kecepatan aliran akan meningkatkan besarnya tekanan udara yang terjadi di sekitar benda uji, sehingga akan berpengaruh terhadap distribusi tekanan dan besarnya gaya hambat.

3. Distribusi tekanan udara akan berubah apabila terjadi perubahan sudut serang sehingga besarnya gaya hambat akan berubah pula.

4. Pada kepala pesawat, semakin besar sudut serang maka akan meningkatkan besarnya gaya hambat.
[1] Anderson,John D., Fundamentals of Aerodynamics (Mc-Graw Hill Inc., New York, 1991)

[2] Anderson,John D., Computational Fluid Dynamics (Mc-Graw Hill Inc., New York, 1991)
[3] Bertin, J. J. \& Smith, M.L., Aerodynamics For Engineers (Prentice-Hall Inc, New Jersey, 1989)

[4] Currie, I.G., Mechanics of Fluids (Mc-Graw Hill Inc., New York, 1993) 
[5] Garde,R.J. \& A.G. Mirajgacker, Engineering Fluid Mechanics (NEM Chand \& Bros. India, 1983)

[6] Hoerner, Sighard F., Fluid-Dynamic Drag (Gibbs \& Cox, Inc., New York City, 1965)

[7] Mathews, John H., Numerical Methods (Prentice Hall Inc. New York, 1992)

[8] McCormick, Barners W., Aerodynamics, Aeronautics, And
Flight Mecanics (John Wiley \& Sons Inc, Canada, hlm. 50-51, 1979)

[9] NASA. 2002. Incompressible Flow Around A Cylinder and A Wing Section (2002) http://www.allstar.fiu.edu/ aeronautic/fluidynamics/level3, 27 Mei 2006. 